\title{
Factors Influencing Market Participation among Sesame Producers in Benue State, Nigeria
}

\section{Nwalem Monday Patrick ${ }^{1}$, Ukpe Udeme Henrietta ${ }^{2}$, Djomo, Raoul Fani ${ }^{1}$, Dzever Donald ${ }^{1}$}

${ }^{1}$ Department of Agricultural Economics, University of Agriculture, Makurdi. Makurdi, Benue State, Nigeria

${ }^{2}$ Department of Agricultural Economics and Extension, Federal University Wukari, Wukari, Taraba State, Nigeria

\begin{abstract}
Farmers' participation to agricultural business is a prerequisite for their sustainability. Encouraging sesame producers to market participation has the potential to facilitate poverty alleviation by transforming subsistence agriculture to commercial agriculture as well as unlock the well known benefits of trade. This Study was therefore undertaken to analyze factors influencing market participation among sesame producers using binary regression. A combination of purposive and random sampling techniques was used for sample selection. Data were obtained through the use of a structured questionnaire, copies of which were administered to the selected 372 sesame farmers in Benue State. The result indicated that Cox\&Snell (R square) is 0.57 implying that sex; age; marital status; household size; education; farming experience; size of farm; output and market information accounted for 57 percent factors influencing market participation by sesame farmers in Benue State, Nigeria. The result further indicated that education; size of farm and output were factors that influence market participation by sesame farmers as well as lack of information (19.95\%); Seasonality (18.10\%); poor storage facilities (17.52\%); cost of transportation (13.70\%); High taxes (12.14\%); Distance to market $(9.60 \%)$ and bad road (8.96\%) were constraints faced by sesame producers. It was recommended that sesame producers should be properly informed on the market price through media and this will be achieved by setting a price control and also investment on physical infrastructure (road network, warehouse, etc....) should be done in remote areas.
\end{abstract}

Keywords: Factors, Influence, Market participation, Sesame producers

\section{INTRODUCTION}

One important route to reduce poverty in rural areas is to enhance the market participation of rural farmers, as this can increase the net returns to agricultural production (World Bank, 2007). Many farmers in Sub-Saharan Africa, however, remain subsistence farmers whose production activities are conducted mainly for home consumption (Verheye, 2000). One reason for remaining at the subsistence farming level is the high cost of marketing. Better access to information is expected to reduce such costs and to encourage farmers to participate in markets by increasing the returns to their products (Jensen, 2007). Barrett (2008) highlights the need to establish when barriers to market participation are related to household assets or technologies that can be used to generate surpluses large enough to induce crop sales, and when barriers have stronger linkages to deficiencies in physical infrastructure and market structures. UBOS (2006) show a lack of market orientation, with more than $75 \%$ of agricultural households selling less than $25 \%$ of their total crop output. Ana et al. (2008) explains that the poorest people in the world are farmers with low market participation and low agricultural productivity. Increasing either one could help to improve the other, and both could boost living standards: higher market participation could drive productivity by providing incentives, information and cash flow for working capital, while higher productivity could drive market participation since households with higher productivity are more likely to have crop surpluses above their immediate consumption needs. Sesame is one of the cultivated oil seed crops in the world. Following Onyibo et al. (2005) and Nwalem (2015), since its introduction to Nigeria after the Second World War, it has been regarded as a crop of insignificant importance compared to groundnut and other cash crops. Sesame is widely grown in the Northern and Central part of the country initially as a 
minor crop until 1974, when it become one of the major cash earner in many northern states such as Benue, Gombe, Kogi, Jigawa, Kano, Nasarawa, Katsina, Plateau, and Yobe States as well as the Federal Capital Territory. The demand for sesame and its products is growing both at the National and International levels. Thus huge market potential exists for sesame. Owing to its previous status as a minor crop, there has been little research efforts on the crop. The crucial issue in this study is whether sesame output supply can keep pace with increase demand under the market condition. This will depend; both on the scope for raising agricultural productivity (including reducing waste during resource utilization in production), availability of inputs used in the agricultural sector (land, labour, machinery, water resources, fertilizers, etc.) and having sufficient information for possible effective adaptation of market strategies (Nwalem, 2015). Consequently, attempt is being made in this study to analyze factors influencing market participation among sesame producers as well as constraints that affect their participation to market.

\section{Methodology}

The Study Area: Benue State derives its name from River Benue, the second largest River in Nigeria. The State, created in 1976, is located in the middle Belt region of Nigeria, approximately between latitudes $612^{0}$ and $812^{0}$ North and longitude $71 / 2^{0}$ and $10^{0}$ East. The State shares boundaries with five states namely, Nasarawa to the North, Taraba to the East, Cross River to the South-East, Enugu to the South- West, and Kogi to the West. The Southern part of the State also shares boundary with the Republic of Cameroon. The State is also bordered on the North by $280 \mathrm{~km}$ River Benue, and is traversed by $202 \mathrm{~km}$ of River Katsina-Ala in the inland areas. Benue State has a tropical climate, which manifests two distinct seasons. The rainy season is from April to October while the dry season is from November to March. Annual average rainfall varies from $1750 \mathrm{~mm}$ in the Southern part of the State to $1250 \mathrm{~mm}$ in the North.

Population, Sampling Procedure and Data Collection: A combination of purposive and random sampling techniques were used for sample selection. Benue State is divided into three (3) agricultural zones such as: Zone A, Zone B and Zone C. Two local government areas each were purposely selected from Zone A and Zone B while three local government areas were purposely selected from zone $\mathrm{C}$ on the basis of high level of sesame production. Based on this, Kwande and Logo Local Government Areas were purposively selected from Zone A. Guma and Tarka Local Government Areas were purposively selected from Zone B. Oju, Obi and Ohimini Local Government Areas were purposively selected from Zone C. From each of the selected Local Government Areas, households were randomly selected on the basis of its population size using $0.2 \%$ sampling fraction. Based on the foregoing, 372 sesame producers were randomly selected for this study. The primary data were obtained through the use of a structured questionnaire, copies of which were administered to the selected 372 sesame farmers in Benue State.

\section{Variable Specification/Model Specification}

\section{Binary Logistic Regression Model}

$\mathrm{Z}=\log \lfloor\mathrm{P} / 1-\mathrm{P}\rfloor=\log \mathrm{Y}=\beta_{0}+\beta_{1} \mathrm{X}_{1}+\beta_{2} \mathrm{X}_{2}+\beta_{3} \mathrm{X}_{3}+\beta_{4} \mathrm{X}_{4}+\beta_{5} \mathrm{X}_{5}+\beta_{6} \mathrm{X}_{6}+\beta_{7} \mathrm{X}_{7}+\beta_{8} \mathrm{X}_{8}+$ $\beta_{9} X_{9}+\varepsilon$

Where $\mathrm{Z}=$ Probability of having access to credit

market participant $=1$ Non market participant $=0$

$\mathrm{P}=$ Probability of farmers of being a market participant

$1-\mathrm{P}=$ Probability of farmers not being a market participant

$\beta_{1}, \beta_{2}, \beta_{3}, \beta_{4}, \beta_{5}, \beta_{6}, \beta_{7}, \beta_{8}, \beta_{9}$ are regression coefficients explaining changes in the independent variables

$\mathrm{X}_{1}=\operatorname{Sex}($ male $=1$ female $=0)$

$\mathrm{X}_{2}=$ Age (in years)

$\mathrm{X}_{3}=$ Marital status (married $=1$, single $=2$, divorced $=3$, widowed $/$ widower $=4$ )

$\mathrm{X}_{4}=$ Household size (number of members in the house)

$\mathrm{X}_{5}=$ Education (in years) 
$\mathrm{X}_{6}=$ Farming experience (in years)

$\mathrm{X}_{7}=$ Size of farm (in hectares)

$\mathrm{X}_{8}=$ Output $(\mathrm{kg})$

$\mathrm{X}_{9}=$ Market information $(\mathrm{yes}=1$, no $=0$ )

\section{RESULTS AND DISCUSSION}

\section{Factors Influencing Market Participation of Sesame Farmers in Benue State, Nigeria}

Table 1 summarized binary logistic regression estimates of factors influencing market participation of sesame farmers in Benue State, Nigeria which includes sex; age; marital status; household size; education; experience; size of farm; output and awareness. As indicated in table 1, Cox\&Snell (R square) is 0.57 implying that sex; age; marital status; household size; education; farming experience; size of farm; output and market information accounted for 57 percent factors influencing market participation by sesame farmers in Benue State, Nigeria. The result further indicated that education; size of farm and output were factors that influence the intensity of market participation by sesame farmers. Specifically, the coefficient for education is positive and significant and 1 percent implying that education increase probability of being market participant among sesame farmers by 1.79 . This may be explained by the fact that educated farmers have the capacity to follow update in market fluctuation. The coefficient for size of farm is positive and significant at 1 percent implying size of farm increase the probability of being market participant among sesame farmers to participate in the market by 3.15. This may be explained by the fact that the larger the farm size is the higher output is. Finally, the coefficient for output is positive and significant at 1 percent implying output increase the probability of being market participant among sesame farmers by 0.99 . This result is in line with the finding of Omiti et al. (2009) who found that increased in output increase the probability of smallholder Kenyan's farmers to participate in the market. However, the coefficients for sex; age; marital status; household size; experience and market information were not significant implying that these variables have no significant influence on market participation of sesame farmers in Benue State, Nigeria.

Table1. Binary Logistic Regression Estimates of factors influencing market participation of sesame farmers in Benue State, Nigeria

\begin{tabular}{|l|l|l|l|l|l|}
\hline Variables & Coefficients & S.E & Wald & Sig & Exp (B) \\
\hline Sex (1) & 0.18 & 0.30 & 0.37 & 0.53 & 1.20 \\
\hline Age & 0.09 & 0.01 & 0.53 & 0.46 & 1.01 \\
\hline Marital Status & & & 7.47 & 0.11 & \\
\hline Married (1) & -22.04 & $2.83 \mathrm{E} 4$ & 0.00 & 0.99 & 0.00 \\
\hline Single (2) & -22.88 & $2.83 \mathrm{E} 4$ & 0.00 & 0.99 & 0.00 \\
\hline Divorced (3) & -24.83 & $2.83 \mathrm{E} 4$ & 0.00 & 0.99 & 0.00 \\
\hline Widowed (4) & -0.31 & $3.19 \mathrm{E} 4$ & 0.00 & 1 & 0.73 \\
\hline Household size & -0.08 & 0.16 & 0.26 & 0.61 & 0.92 \\
\hline Education & 0.58 & 0.13 & 19.96 & $0.00^{*}$ & 1.79 \\
\hline Experience & -0.16 & 0.14 & 1.24 & 0.26 & 0.84 \\
\hline Size of farm & 1.15 & 0.22 & 27.22 & $0.00 *$ & 3.15 \\
\hline Output & 0.04 & 0.001 & 26.78 & $0.00^{*}$ & 0.99 \\
\hline Market information & & & 0.00 & 1 & \\
\hline Market information (1) & 43.41 & $2.67 \mathrm{E} 4$ & 0.00 & 0.99 & $7.18 \mathrm{E} 18$ \\
\hline Market information (0) & 19.44 & $1.76 \mathrm{E} 4$ & 0.00 & 0.99 & $2.79 \mathrm{E} 8$ \\
\hline Constant & -0.94 & 0.871 & 0.012 & 0.914 & 0.91 \\
\hline log likelihood & 319.431 & & & & \\
\hline Cox\&Snell R square & 0.57 & & & & \\
\hline Nagelkerde R square & 0.66 & & & & \\
\hline Classification table & 60.8 & & & & \\
\hline
\end{tabular}

Source: Field Survey, $2015 \quad$ *significant at $1 \%$

\section{Constraints to Market Participation Faced by Sesame Producers}

Table 2 indicates constraints to market participation faced among sesame producers in Benue State, Nigeria. The result revealed that majority of sesame producers are faced with the problem of lack of 


\section{Nwalem Monday Patrick et al.}

information (19.95\%) which may be due to the fact that there is no price control and therefore give provision to middlemen to take advantage on producers. Seasonality $(18.10 \%)$ is another constraint faced by sesame farmers which may be explained by the fact that it is not always available through all the year and therefore restricts most farmers to be in the market. Another constraint is poor storage facilities (17.52\%) which may be due to the fact there is absence of community warehouse in the study area. The study further revealed that cost of transportation (13.70\%) is another constraint to market participation which may be due to the removal of fuel subsidies in Nigeria. High taxes (12.14\%) is another constraint faced by sesame farmers in the study area which may be attributed to the strategy put in place by local government in order to generate internal revenue. Distance to market (9.60\%) and bad road (8.96\%) are another constraints faced by sesame farmers and these may be due to the fact that sesame production is mostly carried out in remote areas which are always less develop.

Table 2. Constraints to market participation faced by sesame producers

\begin{tabular}{|l|l|l|}
\hline Constraints & Frequency & Percentage (\%) \\
\hline Lack of information & 345 & 19.95 \\
\hline Seasonality & 313 & 18.10 \\
\hline Poor storage facilities & 303 & 17.52 \\
\hline Cost of transportation & 237 & 13.70 \\
\hline High taxes & 210 & 12.14 \\
\hline Distance to market & 166 & 9.60 \\
\hline Bad road & 155 & 8.96 \\
\hline Total & $\mathbf{1 7 2 9}$ & $\mathbf{1 0 0}$ \\
\hline
\end{tabular}

Source: Field Survey, 2015 multiple responses recorded

\section{CONCLUSION AND RECOMMENDATIONS}

This study analyzes factors influencing market participation among sesame farmers as well as constraints that affect their participation to market. The result indicated that education; size of farm and output were factors that influence the intensity of market participation by sesame farmers as well as lack of information (19.95\%); Seasonality (18.10\%); poor storage facilities (17.52\%); cost of transportation (13.70\%); High taxes (12.14\%); Distance to market $(9.60 \%)$ and bad road (8.96\%). It is therefore concluded that sesame farmers relatively participate to market. It is recommended that:

i) Sesame farmers should be properly informed on the market price through media and this will be achieved by setting a price control

ii) Investment on physical infrastructure ( road network, warehouse....) should be done in remote areas

\section{REFERENCES}

[1] Ana, R.R, W. A. Masters and G. E. Shively, 2008. Linkages between Market Participation and Productivity: Results from a Multi-Country Farm Household Sample.

[2] Barrett CB (2008). Smallholder market participation: concepts and evidence from Eastern and Southern Africa. Food Policy 33: 299-317.

[3] Jensen, R. (2007). The Digital Provide: Information (Technology), Market Performance, and Welfare in the South Indian Fisheries Sector. The Quarterly Journal of Economics, Vol. 122 (3): 879-924

[4] Nwalem, M.P. (2015). Relationship between level of adverse effect of perceived dimensions of climate change manifestations and production efficiency among sesame farmers in Benue State, Nigeria. M.Sc. Thesis submitted to the Department of Agricultural Economics. University of Agriculture, Makurdi-Benue State, Nigeria.

[5] Omiti, J.M., Otieno, D.J., Nyanamba, T.O., and Mccullough, E. (2009). Factors influencing the intensity of market participation by smallholder farmers: A case study of rural and peri-urban areas of Kenya. Afjare Vol 3 (1): 57-82

[6] Onyibo, J.E., Tologbonshe, E.B. and Ubi, E.O. (2005). Beniseed Production and Utilization in Nigeria. National Agricultural Extension and Research Liaison Services. Extension Bulletin No. 154, Horticulture Series No. 5, 23 pp. 
[7] UBOS (2006).Uganda national household survey 2005/2006 mid-term report. Ugandan Bureau of Statistics, Kampala.

[8] Verheye, W. (2000). Food Production of Food Aid?: An African Challenge, Finance and Development. Volume 37, No. 4.

[9] World Bank (2007). World Development Report 2007: Agriculture for Development, Washington D.C. 